\title{
EUROPEAN FINANCIAL SUPPORT AND SUCCESFUL ROAD PPP PROJECTS
}

\author{
Laura Garrido \\ PhD. Candidate, Centro de Investigación del Transporte (TRANSyT), Universidad \\ Politécnica de Madrid, Spain \\ María de los Ángeles Baeza \\ Assistant Professor, Departamento de Economía Financiera y Contabilidad, Universidad de \\ Granada, Spain \\ José Manuel Vassallo \\ Associate Professor, Centro de Investigación del Transporte (TRANSyT), Universidad \\ Politécnica de Madrid, Spain
}

\begin{abstract}
The EU has been promoting the use of PPPs in order to accelerate the development of the Trans-European Transport Network (TEN-T) for ensuring economic, social and territorial cohesion and increasing accessibility throughout the Union. To encourage the use of PPPs, the European Commission has put several financing mechanisms at the disposal of the Member States, including a series of innovative financial instruments developed along with the European Investment Bank. The Bank has in turn played a major role in the promotion and financing of PPPs across the EU.
\end{abstract}

The paper undertakes a review of the main financial instruments developed by the EU that are available to PPPs so as to determinate to what extent the European financial support has been channelled to road projects under that scheme in Spain. On the basis of the results obtained, a multiple regression model has been developed to analyse whether the PPP projects which enjoyed the financial support of the European Union tend to be significantly more successful from an economic point of view. The paper concludes that there is a positive correlation between receiving European financial support and the success of the PPP road projects.

\section{INTRODUCTION}

It was not until the Treaty of Maastricht in 1992 when the foundations of a common transport infrastructure policy and the instruments for its funding were endorsed to boost the development of the Trans-European Networks for transport (TEN-T). Public Private Partnerships (PPPs) have been always regarded by the European Commission as a key instrument to promote infrastructure projects within the TEN-T network (European Commission, 2008), but its interest in that mechanism started to grow given the large existing funding gap in the TEN-T projects.

Since then, a clear policy from the European Commission to support public-private 
partnerships so as to leverage private financing for public infrastructure projects, especially in the transport sector, can be noted. The European Commission has reformed the procurement rules; has worked in the progressive removal of technical (European Commission, 2003), legal (Commission of the European Communities, 2004), administrative and accounting barriers (EUROSTAT, 2004); and has increased the European financial resources available for PPPs, including the creation of a series of innovative financial instruments (Zaharioaie, 2012).

Spain is one of the countries with the greatest tradition in the use of private financing for the promotion of infrastructure, especially in the field of transport, currently being one of the EU countries with the highest volume and number of PPP projects (Inderst, 2013). Although nowadays PPPs are being used for almost any kind of infrastructure, the model has been mostly implemented in the road sector by both the national and the regional governments. Moreover, Spain has enjoyed a great amount of EU financial support, which makes it a very interesting case to be analysed.

The aim of this paper is twofold. On the one hand, to carry out a qualitative and quantitative evaluation with regard to the EU financial mechanisms available to road PPP projects (mainly subsidies and loans granted by the European Union and the European Investment Bank, and the Financial Instruments they have developed together). On the other hand, to make a statistical analysis to assess whether the EU financial support has influenced the economic performance of the selected projects.

The paper is structured as follows. After this introductory chapter, Section 2 develops a review of the main European financing instruments currently available for road PPP projects. Section 3 analyses the extent to which the projects under that scheme have benefited from the mechanisms under review. Section 4 outlines the methodology of this research. Section 5 presents and discusses the main results. Finally, Section 6 sets out the main conclusions and points out further research.

\section{REVIEW OF THE EU FINANCIAL INSTRUMENTS SUPPORTING ROAD PPP PROJECTS}

According to EPEC (2011), the EC has settled three different groups of financial instruments available to PPP projects:

Grants that support the cohesion policy of the Union and individual EU Member States. Grants from Cohesion Fund (CF) and European Regional Development Fund (ERDF) account for the largest amount of funding potentially available to PPPs. Nevertheless, these grants are only available for those Member States less developed of the EU. 
Sectorally focused grants that promote investments in projects of pan-European interest. For instance, the TEN-T program and its successor the Connecting Europe Facility (CEF) are explicitly open to PPP projects that implement TEN-T schemes. Unlike the ERDF and the CF, every Member State, regardless of its level of development, is eligible to receiving financing from these programmes.

Financial engineering instruments that leverage private finance so as to make PPP projects financially bankable. Some of these instruments are used to cover some of the project risks associated to PPP projects, whilst others try to supply the lack of sufficient equity for large infrastructure projects under PPP schemes. The most important ones are the Loan Guarantee Instrument for Trans-European Transport Network Projects (LGTT), designed to encourage and promote private-sector involvement in the financing of the TEN$\mathrm{T}$ projects by covering traffic revenue shortfalls during the initial operating period (rampup); the EU Project Bonds Initiative (PBI), aimed at enhancing the credit quality of project bonds issued by private companies in order to make them more attractive to investors; and the Marguerite Fund (MF), a pan-European infrastructure equity fund established to act as a catalyst in the development of infrastructure in the transport and energy sectors.

Finally, as the European Union's bank, the European Investment Bank (EIB) is one of the largest financiers of PPP projects for transport infrastructure through Europe. In addition to EIB's direct lending activities, the Bank has played a major role in the promotion of PPPs and has become increasingly involved in the dissemination of information and good practices within the public sector and in the structuring and monitoring of PPP projects.

\section{EU FINANCIAL SUPPORT TO ROAD PPP PROJECTS IN SPAIN}

Spain has been the largest beneficiary of both Structural and Cohesion Funds until the enlargement of the EU in 2004. More than $60 \%$ of these resources were allocated to transport infrastructure projects (Dall'Erba, 2003). However, only two of the major projects supported up to date by the ERDF and the CF, were PPPs: the AP-53 (Santiago-Alto de Santo Domingo) toll road in Galicia and the Almanzora - Purchena shadow toll highway in the region of Andalusia. These projects represent only 3.88\% of the ERDF budget allocated to Spain from 2000 to 2013.

Concerning the TEN-T funding, despite the fact that it allows for grant disbursement to private partners and both its rules and its application process are favourable for PPPs (EPEC, 2011), in Spain only one road PPP project has benefited from this grant, in the 2007-2014 period, accounting for just $0.22 \%$ of the whole budget in this period. The new highway A66 from Benavente to Zamora, in which the EU financed the execution of the design and all preparatory documents and studies needed for the construction of the road section and almost $50 \%$ of the works budget. 
Regarding the innovative financial instruments, their scope has been quite modest in Europe in general and particularly in Spain. Only the LGTT and the Marguerite Fund have contributed to finance road PPP projects in Spain. One of the seven projects signed by the LGTT is the C25-Eix Transversal, located in the region of Catalonia, in Spain. On the other hand, in 2012 the Marguerite Fund made its first investment in the transport sector acquiring a 45\% stake in Autovía del Arlanzón, a brownfield TEN-T project in Spain, for $€ 24.5$ million.

With regard to the EIB co-financing, its role in the Spanish road PPP market increased more or less steadily until 2006 before it started to decline - with the exemption of a peak observed in 2010 - as a consequence of the economic crisis and the subsequent decline of PPP projects (see Fig. 2). A sectorial breakdown of the EIB portfolio of PPPs sorted by type of infrastructure is included in Fig. 1, with roads and motorways being second only to the metro, light rail and tramway.
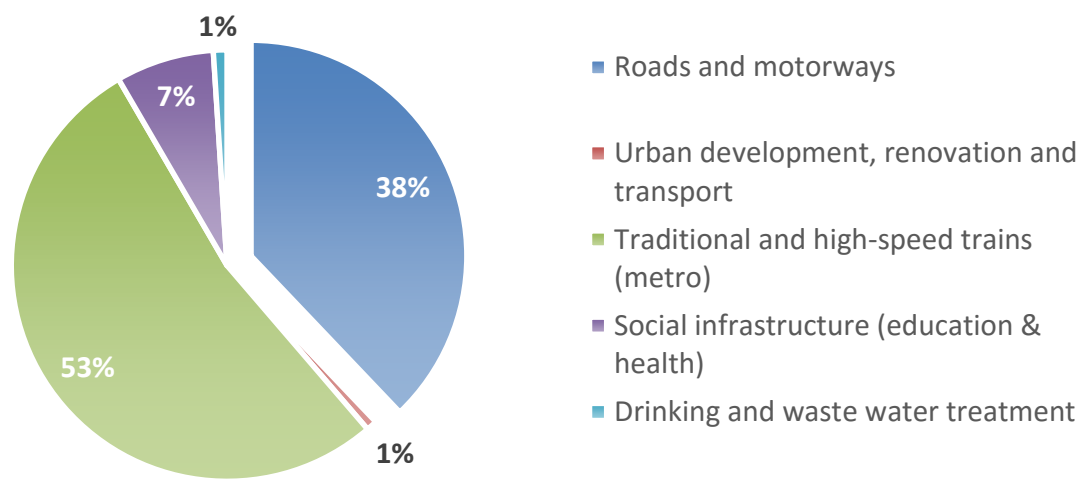

Fig. 1 - EIB loans for PPP road projects from 1990 to 2014 by sector. Source: EIB (2015)

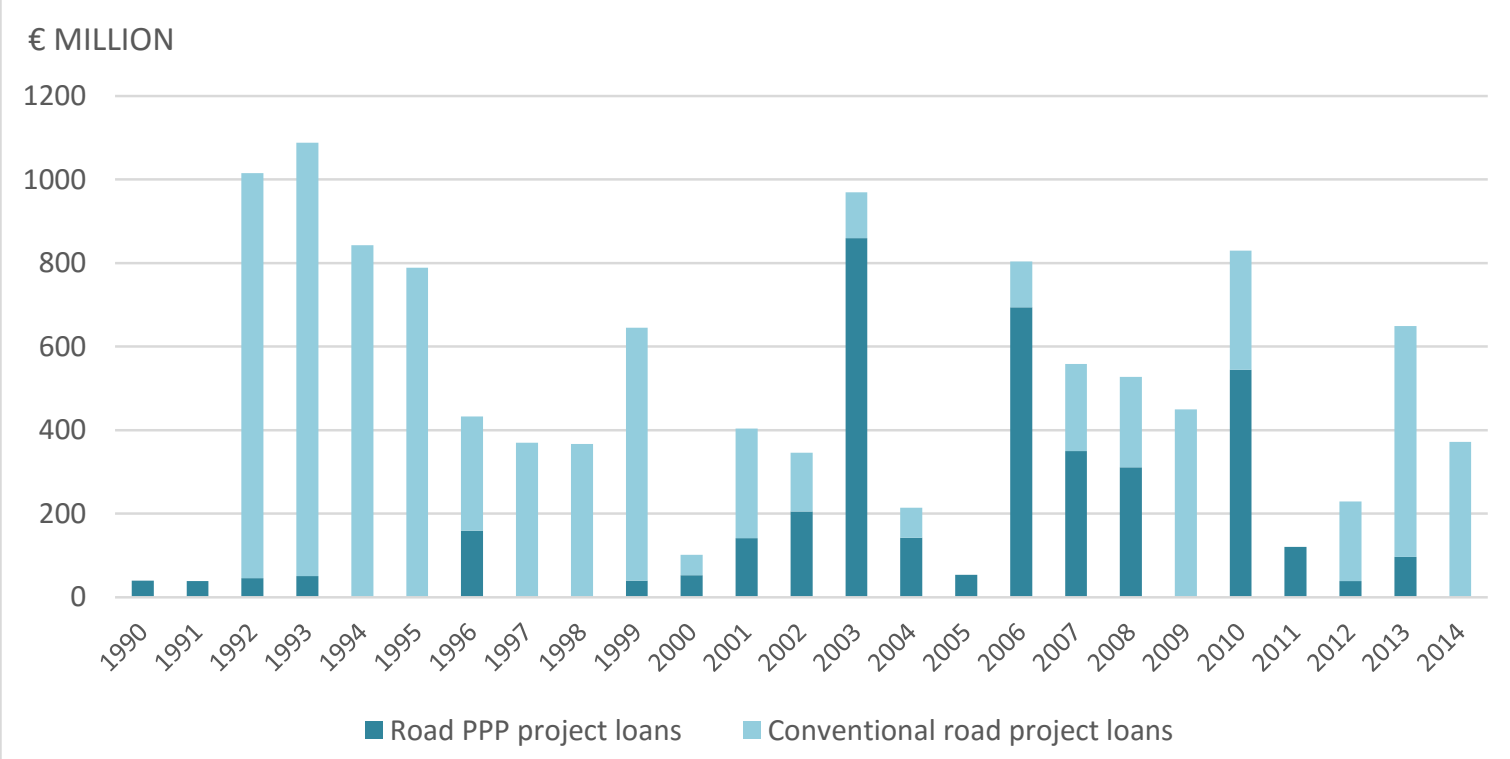

Fig. 2 - Comparison of the volume of loans granted by the EIB to PPP road projects and non PPP projects in Spain in the period 1990-2014. Source: EIB (2015)

This work is licensed under a Creative Commons Attribution-NonCommercial-NoDerivatives 4.0 International License (CC BY-NCND 4.0). 
Fig. 2 shows the volume of loans granted by the EIB to both conventional procurement and PPP projects in the road sector in Spain. Although a greater amount of loans allocated to PPP projects can be noted ever since 2000, in the last few years - with the sole exception of 2010 - the loans to PPPs have been dwindling. This has been caused by a huge decline of the PPP market.

Regarding the relative involvement of the EIB in financing road PPP projects in Spain, it has been quite moderate when compared to other financial sources. The share of road PPP projects financed through EIB loans in Spain in the period from 2003 to 2014 has been just the $11 \%$ of the total volume (European Investment Bank, 2015; SEOPAN, 2015).

\section{METHODOLOGY}

In order to analyse to what extent having EU financial backing has a positive influence on the success of the road PPP projects developed in Spain, a multiple regression model has been developed. To that end, it was decided to establish the methodology presented in this section, whose main steps are shown in Fig. 3. The case study chosen for the analysis is the Spanish case and comprises all PPP projects carried out between 1999 and 2009 in the field of road infrastructure. This selection is based on a number of reasons: the great amount of EU financial support received by Spain, the existence of a large number of road PPP projects, the Spanish long tradition and extensive experience in developing PPPs and with the aim of analysing a heterogeneous case.

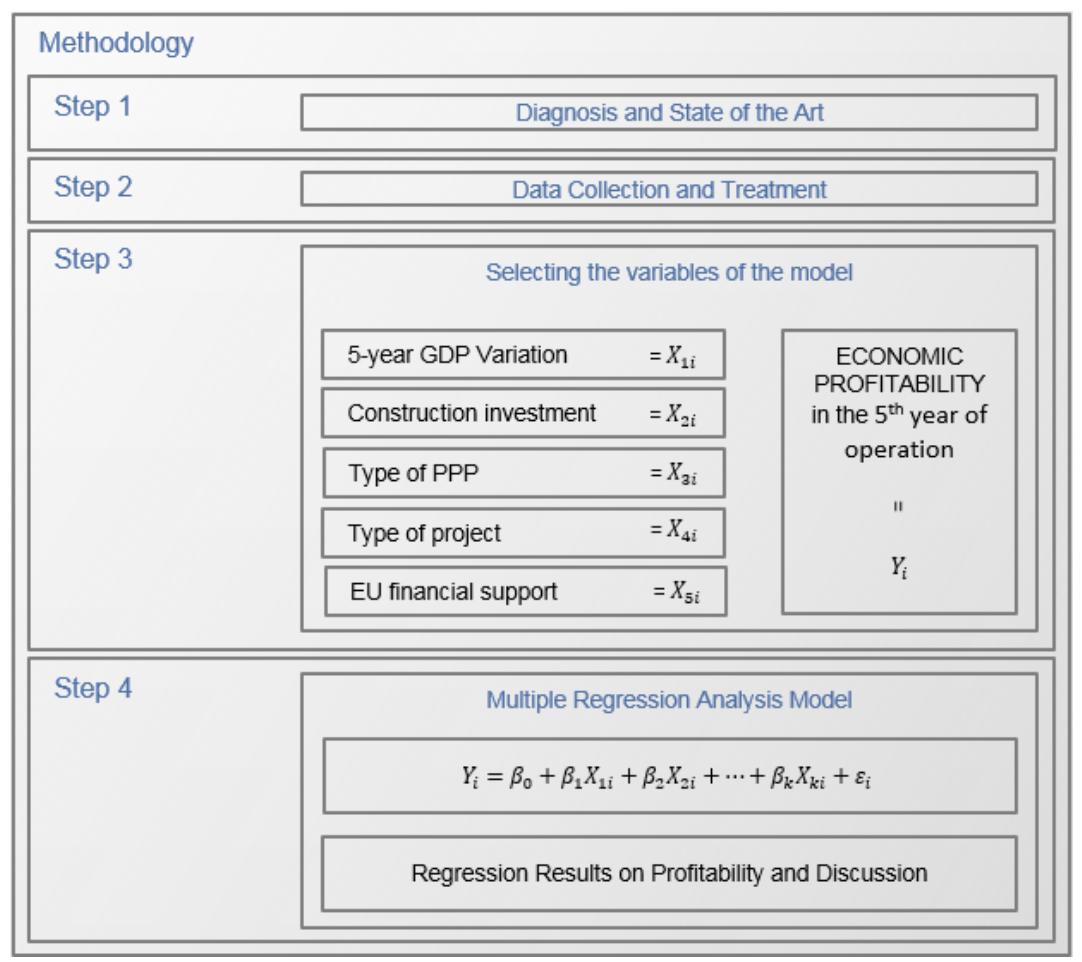

Fig. 3 - Methodology scheme 


\subsection{Data collection and treatment}

The research involved analysing a sample comprising all the road PPP projects awarded between 1999 and 2009 in Spain (See Fig. 4). Data for tolled motorways were compiled from the annual reports of the Spanish Ministry of Transport (Ministerio de Fomento, 2013); the previous research conducted by Vassallo and Pérez de Villar (2010) on shadow toll motorways allowed us to complete the road PPP projects database.

Once the PPP projects were identified, an in-depth analysis of the European and Spanish working papers in terms of European-financial assistance was carried out in order to complete the database with the financial support received by each project. Finally, an exhaustive review of the current literature on factors affecting the performance of projects (usually called project success factors) and measures of project performance was conducted in order to select both the explanatory and the dependent variables of the model.

Regarding the obtaining of the variables, the economic profitability and the construction investment were calculated with the data from the unconsolidated annual accounts of each concessionaire. Concerning the 5-year GDP variation, the data were collected from the National Institute Office (Instituto Nacional de Estadística, 2014). In order to better consider the influence that the local economic environment might have in the profitability of each road section, data was collected at the provincial level. In this respect, each road was assigned the total GDP of the provinces it crosses, in contrast to adopting an average national GDP evolution for the whole road network analysed.

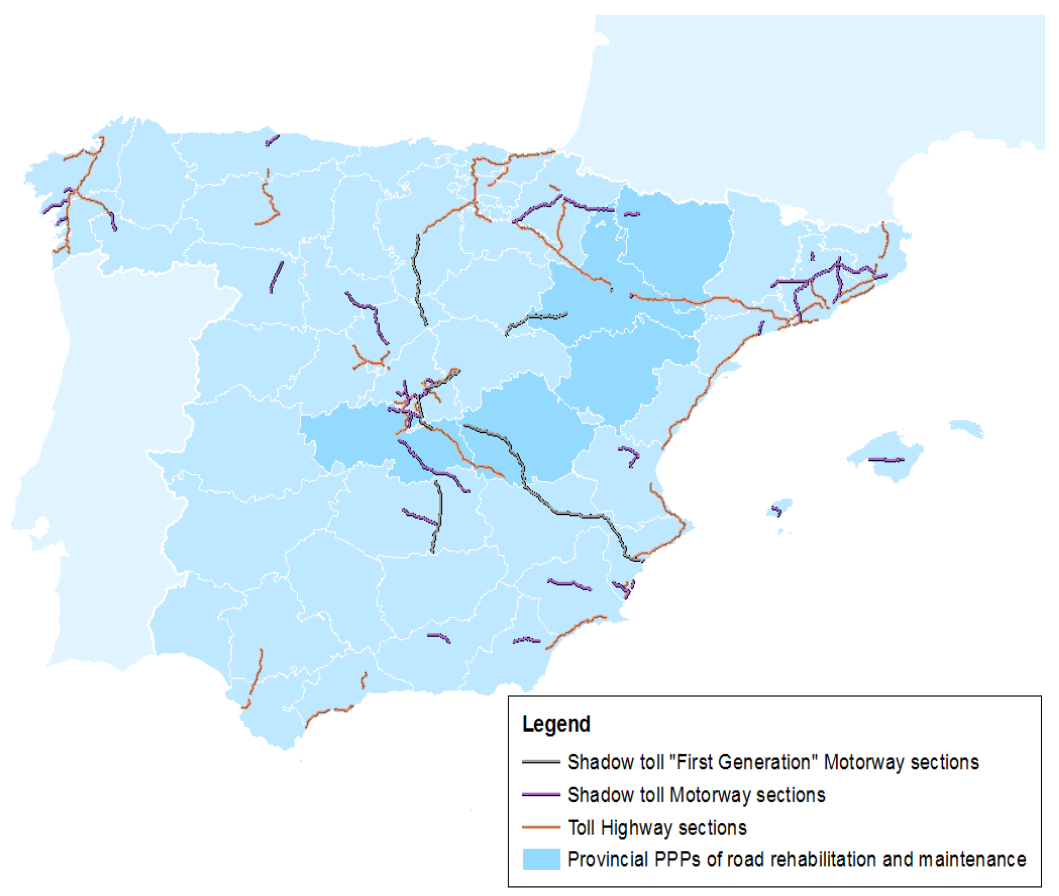

Fig. 4 - Database of road PPP projects in Spain

\subsection{Selecting the variables of the model}

In this approach it was decided to adopt an economic ratio to measure the PPP projects 
performance from an economic perspective. Particularly we selected the economic profitability (EP) measured as the ratio between the gross annual profit and the total assets included in the balance sheet of each PPP company. This variable is objective, measurable, available for every project and has been used before by several authors (Horta, Camanho, \& Moreira Da Costa, 2012; Kangari, Farid, \& Elgharib, 1992).

Profitability is a proper measure of the economic success of the project and, in a context of increasing competition, concessionaires are aware that the project must be properly managed to be profitable (Parfitt \& Sanvido, 1993). Furthermore, profitability is considered a critical criterion for a project to be successful by Project Managers (Menches \& Hanna, 2006) and the most important one for public sector clients (Kušljić \& Marenjak, 2013). But it is even more important in PPP projects, where there is a clear incentive to hasten the construction phase so as to accelerate the rate of return. Moreover, as a performance measurement, profitability can be taken as a key indicator of the performance of the project over time, acting as a tool for continuous improvements (Takim \& Akintoye, 2002).

Profitability is measured in the post-construction phase, when the final account is settled and the financial result can be assure (Chan, Scott, \& Lam, 2002). Particularly, to account for the economic profitability in the modelling approach we considered the $5^{\text {th }}$ year of operation of each project. This enables avoiding the so-called period of ramp-up, comprising the first years of operation of a certain road. This period is characterized by greater interannual instability of road demand levels and consequently of its economic profitability, potentially showing a non-representative picture of the project performance in the medium- and longterm.

Concerning the explanatory variables of the model, their selection has been based both on the objectives of the research and on a detailed literature review on project success factors. These are the independent variables that might affect the performance of a project (Hardcastle, Edwards, Akintoye, and Li, 2005; Zhang, 2005).

(1) Favourable investment environment factors, such as stability of economic environment in the country or the existence of service need, were encompassed in the GDP variable; its variation in the first five years since the adjudication of the project will capture the effect of the macroeconomic conditions on its profitability. Moreover, as traffic demand is elastic with respect to the level of economic activity (Gomez, Vassallo, \& Herraiz, 2015), the GDP variable will capture its evolution as well.

(2) The construction cost of the project was included as a control variable of the investment size.

(3) Four dummy variables were considered in the model in order to capture additional effects regarding the type of concession and the type of project. Both the type of concession (explicit toll, shadow toll and availability payment) and the type of 
project (greenfield, brownfield or unfolded road) were taken into account as categorical variables, being explicit toll and greenfield road the reference cases in the model.

(4) Finally we included the main objective of this research, a categorical variable indicating whether the project has been supported by the EU or not.

\subsection{Selection of the econometric model}

The Multiple regression technique is a statistical specification widely used to analyse the functional relationship between several explanatory variables and a single dependent variable, in order to explain the variation in the dependent variable as a result of changes in the explanatory or independent variables. Hence, multiple linear regression analysis was employed to model the relationships between the economic profitability (dependent variable) and a set of success factors (explanatory variables) for road PPP projects in Spain (see Fig. 3). The regression equation can be expressed as follows:

$$
Y_{i}=\beta_{0}+\beta_{1} X_{1 i}+\beta_{2} X_{2 i}+\cdots+\beta_{k} X_{k i}+\varepsilon_{i} ; \quad i=1, \ldots, N
$$

where $\beta_{0}$ represents the intercept while $\beta_{1}, \beta_{2}, \ldots, \beta_{k}$ are regression coefficients which denote the estimated change in the dependent variable $\mathrm{Y}$ for a unit change of the independent variables $X_{1}, X_{2}, \ldots, X_{k}$. The prediction error $\left(\varepsilon_{i}\right)$ or the residual, is the difference between the actual and predicted values of the dependent variable. Once the model is developed, the adjusted coefficient of determination (adjusted R2) is calculated to reflect the goodness of fit thereof.

\section{REGRESSION RESULTS AND DISCUSSION}

Table 1 includes the modelling results from the multiple regression analysis. Given the significance level of every explanatory variable, it is possible to assure that the type of concession, the economic environment and the EU financial support are critical success factors for the economic performance of road PPP projects. By contrast, the type of project did not evidence to be an explanatory factor significantly affecting the economic profitability. Regarding the goodness-of fit of the model, the $46.6 \%$ of variance of the Economic Profitability can be explained by these three success factors. In addition, the signs of the regression coefficients and their statistical significance are consistent with the expected results.

The results obtained show that the type of PPP is correlated to its economic profitability, and consequent success. The model appoints that both shadow toll and availability payment PPPs tend to be more economically successful than the tolled ones. Moreover, the availability payment should be regarded in first instance as the best option whenever a PPP project is considered to be implemented, given the higher probability of being economically successful. 


\begin{tabular}{lccc}
\hline Model's variables & $\begin{array}{c}\text { Unstandardized } \\
\text { beta coefficients }\end{array}$ & $\begin{array}{c}\text { Unstandardized } \\
\text { typ. error } \\
\text { coefficients }\end{array}$ & $\begin{array}{c}\text { Significance } \\
\text { level }\end{array}$ \\
\hline (Constant) & -2.340 & 0.940 & 0.017 \\
\hline $\begin{array}{l}\text { Type of PPP } \\
\text { Explicit toll (base case) } \\
\text { Shadow toll }\end{array}$ & 3.475 & & \\
$\quad$ Availability payment & 5.502 & 0.787 & 0.000 \\
\hline 5-year GDP variation & 0.077 & 1.416 & 0.000 \\
\hline EU financial support & 0.938 & 0.032 & 0.022 \\
\hline $\begin{array}{l}\text { Type of project } \\
\text { Greenfield (base case) }\end{array}$ & & 0.536 & 0.087 \\
$\quad \begin{array}{l}\text { Brownfield road } \\
\text { Road Widening }\end{array}$ & 0.796 & 0.853 & 0.356 \\
\hline $\begin{array}{l}\text { Total construction } \\
\text { investment }\end{array}$ & -0.589 & 0.601 & 0.332 \\
\hline $\begin{array}{l}\text { Adjusted } R^{2} \\
\text { No. of observations }\end{array}$ & 0.000 & 0.000 & 0.642 \\
\hline
\end{tabular}

Table 1 - Multiple Regression Analysis for Economic Profitability

The results confirm what might be initially expected, that the economic situation is positively correlated with the economic performance of road PPP projects. That is, if the level of economic activity increases the concession's profitability does it as well.

Regarding the EU financial support, the results obtained were not entirely unexpected, as it might seem logical to assume that any support received by the project might increase its probability of success. The results sustain this theory, as having EU financial support is positively correlated with the economic success of the road PPP projects and the variable is significant at $90 \%$ level of confidence.

Finally, it is worth mentioning that unlike expected, the type of project - that is, greenfield, brownfield or road widening - was not correlated with the profitability of the concession.

\section{CONCLUSIONS}

In the light of the review process, the first conclusion is that despite the continued efforts of the EU to encourage the use of community funds in combination with private funds, the Member States, including Spain, have maintained a preference for supplement them with public funds. Regarding the innovative financial instruments, their scope has been quite modest in Europe in general but particularly in Spain. Finally, with respect to the EIB's lending activity and its involvement in Spanish PPP market, there is a clear preponderance of traditional projects over PPPs in terms of loans granted and the total amount of loans to this type of mechanism has been relatively small compared to the volume of projects. 
Based on the multiple regression analysis, the first conclusion is that there is a significant positive correlation between the European financial support and the economic profitability of the projects. Statistically, the PPP projects that were financially backed by the EU were significantly more profitable. It is therefore necessary for the EU to continue promoting the combination of Community funds and financial instruments available to Member States with private funds for the realization of transport infrastructure through successful public-private partnerships, especially given the low rate of PPP projects that get financing from Community funds.

The second conclusion is that the type of PPP is correlated with its profitability. Both shadow toll concessions and, to a greater extent, availability payment concessions have greater economic returns than explicit toll concessions. This provides further support for the growing Government's trend towards bidding new concessions under availability payment schemes.

\section{ACKNOLEDGEMENTS}

Show gratitude to the Ministerio de Economía y Competitividad for funding the project EU Support mechanism to promote public private partnerships for financing transeuropean transport infrastructure [TRA2012-36590] through the Plan Nacional de Investigación Científica, Desarrollo e Innovación Tecnológica 2008-2011.

\section{REFERENCES}

CHAN, A. P. C., SCOTT, D., \& LAM, E. W. M. (2002). Framework of Success Criteria for Design/Build Projects. Journal of Management in Engineering, 18(3). http://doi.org/10.1061/(ASCE)0742-597X(2002)18:3(120)

COMMISSION OF THE EUROPEAN COMMUNITIES. (2004). Green Paper on PublicPrivate Partnerships and Community Law on Public Contracts and Concessions.

DALL'ERBA, S. (2003). European Regional Development Policies : History and Current Issues (No. 4).

EPEC. (2011). Using EU Funds in PPPs - explaining the how and starting the discussion on the future.

EUROPEAN COMMISSION. (2003). Guidelines for Successful Public - Private Partnerships. Brussels.

EUROPEAN COMMISSION. (2008). TEN-T Implementation of the Priority Projects Progress Report.

EUROPEAN INVESTMENT BANK. (2015). Finance contracts signed. Retrieved from http://www.eib.org/projects/loans/list/index.htm

EUROSTAT. (2004). New decision of Eurostat on deficit and debt Treatment of publicprivate partnerships, Decision 18/2004, 11 February 2004. 
GOMEZ, J., VASSALLO, J. M., \& HERRAIZ, I. (2015). Explaining light vehicle demand evolution in interurban toll roads: a dynamic panel data analysis in Spain. Transportation. http://doi.org/10.1007/s11116-015-9612-3

HARDCASTLE, C., EDWARDS, P. J., AKINTOYE, A., \& LI, B. (2005). Critical Success Factors for PPP/PFI Projects in the Uk Construction Industry: a Factor Analysis Approach. Construction Management and Economics, 23(5), 1-9. http://doi.org/10.1080/01446190500041537

HORTA, I. M., CAMANHO, A. S., \& MOREIRA DA COSTA, J. (2012). Performance assessment of construction companies: A study of factors promoting financial soundness and innovation in the industry. International Journal of Production Economics, 137(1), 84-93. http://doi.org/10.1016/j.ijpe.2012.01.015

INDERST, G. (2013). Private Infrastructure Finance and Investment in Europe.

INSTITUTO NACIONAL DE ESTADÍSTICA. (2014). Spanish Regional Accounting. Retrieved from http://www.ine.es/jaxi/menu.do?type=pcaxis\&path=/t35/p010\&file=inebase $\& \mathrm{~L}=$

KANGARI, R., FARID, F., \& ELGHARIB, H. M. (1992). Financial Performance Analysis for Construction Industry. Journal of Construction Engineering and Management, 118(2), 349-361. http://doi.org/10.1061/(ASCE)0733-9364(1992)118:2(349)

KUŠLJIĆ, D. \&, \& MARENJAK, S. (2013). Critical Ppp/Pfi Project Success Criteria for Public Sector Clients. Tehnicki vjesnik/Technical Gazette, 6339(August), 947-954. Retrieved from http://search.ebscohost.com/login.aspx ?direct=true \&profile=ehost\&scope=site \&autht ype $=$ crawler $\&$ jrnl=13303651\&AN=93360301\&h=5L+ySM/tAeFTRkXSg1EXKdiw WYRBwRLaa2V8gnpt1OZMIfdMyYAvIsD7z6e5tfIXq0I/qCjrVJs9oO4X0+gmvw= $=\& \mathrm{crl}=\mathrm{c}$

MENCHES, C. L., \& HANNA, A. S. (2006). Quantitative Measurement of Successful Performance from the Project Manager's Perspective. Journal of Construction Engineering and Management, 132(12), 1284-1293. http://doi.org/10.1061/(ASCE)0733-9364(2006)132:12(1284)

MINISTERIO DE FOMENTO. (2013). Informe 2013 sobre el sector de autopistas de peaje en España.

PARFITT, M. K., \& SANVIDO, V. E. (1993). Checklist of Critical Success Factors for Building Projects. Journal of Management in Engineering, 9(3), 243-249.

SEOPAN. (2015). Evolución de la licitación de concesiones de obras por tipos de obra y CCAA 2014.

TAKIM, R., \& AKINTOYE, A. (2002). Performance Indicators for Successful Construction Project Performance. In D. J. GREENWOOD (Ed.), 18th Annual Association of Researchers in Construction Management (ARCOM) Conference (Vol. 2, pp. 2-4). Newcastle-upon-Tyne.

VASSALLO, J. M., \& PÉREZ DE VILLAR, P. (2010). Diez años de peaje sombra en España Ten years of shadow tolls in Spain. Revista de Obras Públicas, 3506, 19-30. 
ZAHARIOAIE, M. (2012). Appropriate Financial Instruments for Public-Private Partnership in European Union. Procedia Economics and Finance, 3(12), 800-805. http://doi.org/10.1016/S2212-5671(12)00233-X

ZHANG, X. (2005). Critical Success Factors for Public-Private Partnerships in Infrastructure Development. Journal of Construction Engineering and Management, 131(1), 3-14. http://doi.org/10.1061/(ASCE)0733-9364(2005)131:1(3) 